\title{
Analisis Karakteristik Marshall pada Beton Aspal Lapis Pengikat (Asphalt Concrete-Binder Course) menggunakan Aspal Modifikasi Serbuk Serat Pelepah Batang Pisang
}

\author{
Analysis of Marshall Characteristics on Asphalt Concrete-Binder Course \\ using Modification Asphalt with Fiber Powder of Banana Stems
}

\author{
Desi Widianty*, Ratna Yuniarti, Akmaluddin, Agung Prabowo, Shofia Rawiana \\ Jurusan Teknik Sipil, Fakultas Teknik, Universitas Mataram \\ J1 Majapahit 62 Mataram, INDONESIA. Tel.+62-0370 636126 \\ *corresponding author, email: widiantydesi@unram.ac.id
}

Manuscript received: 15-11-2019. Accepted: 24-12-2019

\begin{abstract}
ABSTRAK
Aspal modifikasi dengan penambahan serbuk serat pelepah batang pisang dapat dilakukan untuk meningkatkan kinerja dari aspal murni. Beton aspal lapis pengikat AC-BC merupakan lapis perkerasan lentur yang berfungsi meneruskan beban menuju lapis pondasi. Sehingga sangat diperlukan kekuatan, keawetan dan kestabilan dari bahan penyusunnya. Untuk itu perlu digunakan aspal modifikasi serbuk serat pelepah batang pisang yang dipakai sebagai bahan ikat pada campuran beton aspal AC-BC. Persentase kadar aspal modifikasi yang tepat sangat menentukan kualitas yang optimum suatu campuran beraspal. Benda uji campuran beton aspal dibuat sebanyak 3 (tiga) sampel untuk setiap variasi kadar aspal 5\%; 5,5\%; 6\%; 6,5\%; dan 7\%. Besarnya kadar aspal optimum dalam campuran dilakukan dengan melalui pemeriksaan volumetrik berupa nilai VMA, VIM, dan VFB serta pemeriksaan mekanis berupa stabilitas, flow dan Marshall Quetient. Hasil analisis data didapatkan bahwa nilai VIM, stabilitas dan MQ semakin menurun seiring meningkatnya kadar aspal modifikasi. Sedangkan nilai VMA, VFB dan flow semakin meningkat seiring meningkatnya kadar aspal modifikasi. Namun demikian dari lima variasi kadar aspal didapatkan kadar aspal 5\% dan 5,5\% yang memenuhi semua syarat spesifikasi campuran beton aspal AC-BC. Untuk menentukan kadar aspal optimum diambil rata-rata dari kadar aspal yang memenuhi persyaratan. Sehingga campuran beton aspal AC-BC akan menghasilkan nilai struktural yang lebih baik pada kadar aspal 5,25\% dengan serbuk serat pelepah batang pisang pada aspal sebesar $0,1 \%$.
\end{abstract}

Kata kunci: AC-BC; serbuk serat pelepah pisang; aspal modifikasi

\begin{abstract}
Asphalt modification by adding fiber powder of banana stem can be implemented to improve the performance of pure asphalt. Asphalt concrete binder course AC-BC is a flexible pavement layer that functions to distribute the load towards the foundation layer. So it really needs strength, durability and stability of the materials. For that, it is necessary to use asphalt modification with fiber powder of banana
\end{abstract}


stem which is used as a binding material in $\mathrm{AC}-\mathrm{BC}$ asphalt concrete mixture. The proper percentage of modified asphalt level will determine the optimum quality of an asphalt mixture. Asphalt concrete specimens were made in 3 (three) samples for each variation of asphalt level by $5 \% ; 5.5 \% ; 6 \% ; 6.5 \%$; and $7 \%$. The asphalt optimum level in the mixture is carried out through volumetric investigation in the form of VMA, VIM, and VFB values and mechanical assessment in the form of stability, flow and Marshall Quetient. The results of data analysis found that the value of VIM, stability and MQ tend to decrease with increasing levels of modified asphalt. On the other hand the value of VMA, VFB and flow tend to rise with increasing levels of modified asphalt. However, from the five variations of asphalt levels obtained asphalt levels of 5\% and 5.5\% which meet all the specifications of AC-BC asphalt concrete specification. To determine the asphalt optimum level, the average of qualified asphalt level is taken. So that the asphalt concrete $\mathrm{AC}-\mathrm{BC}$ will produce a better structural performance at $5.25 \%$ asphalt level with banana stem fiber powder on asphalt by $0.1 \%$.

Keyword: AC-BC; fiber powder of banana stems; asphalt modification

\section{PENDAHULUAN}

Kualitas perkerasan jalan yang baik dapat dinilai dari kemampuan perkerasan tersebut dalam memikul beban lalu lintas. Faktor yang dapat mempengaruhi kualitas perkerasan jalan salah satunya adalah material yang digunakan sebagai bahan jalan. Sehingga sangat diperlukan upaya untuk mendapatkan material bahan jalan dengan kualitas baik atau lebih baik. Penggunaan material bahan jalan yang baik juga harus disertai dengan penggunaan proporsi yang tepat dalam suatu campuran agar menghasilkan perkerasan jalan kuat dalam memikul beban lalu lintas.

Jenis bahan tambah yang digunakan sangat bergantung pada tujuan dan kepentingan yang akan diharapkan. Mashuri (2011) menyatakan bahwa aspal menjadi lebih tahan terhadap perubahan temperatur dan beban lalu lintas berat dengan menambahkan bahan lain yang dapat meningkatkan stabilitas, meningkatkan ketahanan terhadap pengelupasan permukaan perkerasan dan mengurangi kepekaan aspal terhadap perubahan temperatur. Aspal baru yang dihasilkan dari aspal keras dan suatu bahan tambah disebut aspal modifikasi.

Peningkatan kualitas aspal dapat dilakukan dengan menambah serbuk serat pelepah batang pisang. Widianty (2018a) menyatakan bahwa penambahan $0,1 \%$ serbuk serat pelepah batang pisang pada aspal murni 60/70 dapat menurunkan nilai penetrasi dan nilai daktilitas serta meningkatkan nilai titik lembek aspal. Hal ini membuat aspal menjadi lebih tahan pada temperatur yang lebih tinggi.

Laston sebagai lapis pengikat (AC-BC) merupakan lapisan yang terletak di bawah lapisan aus. Tidak berhubungan langsung dengan cuaca tetapi perlu memiliki stabilitas untuk memikul beban lalu lintas yang dilimpahkan melalui roda kendaraan. Campuran beraspal yang terdiri dari aspal dan agregat harus memenuhi syarat stabilitas, fleksibilitas, durabilitas dan tahanan geser. Penggunaan gradasi rapat menghasilkan kepadatan yang baik sehingga stabilitasnya tinggi, tetapi memiliki rongga pori yang kecil yang berarti memberikan kelenturan (fleksibilitas) yang kurang baik. Akibat tambahan beban lalu lintas serta pengaruh cuaca akan memberikan tahanan geser yang kecil. Penggunaan gradasi terbuka, akan diperoleh kelenturan yang baik namun stabilitasnya menjadi kecil. Kadar aspal yang terlalu sedikit menyebabkan lapis pengikat antar butiran kurang sehingga mudah lepas dan durabilitasnya berkurang. (Sukirman, 2016) 
Campuran beton aspal AC-WC menghasilkan kinerja campuran yang paling baik pada penggunaan aspal modifikasi serbuk serat pelepah batang pisang 0,1\% dengan kadar aspal optimum 5,5\%. Hubungan dan antara variasi kadar aspal 5,0 - 7,0\% dengan parameter kinerja menunjukkan bahwa semakin tinggi kadar aspal nilai VMA, VIM dan MQ semakin menurun, sedangkan nilai VFB dan flow semakin meningkat. Serta nilai stabilitas dan Marshall Quetient semakin meningkat tapi sampai batas tertentu yaitu pada kadar aspal 6\% nilainya menjadi turun. Namun kadar aspal yang memenuhi syarat spesifikasi adalah nilai VMA 5\% dan 5,5\%, nilai VIM adalah 5,5\%, nilai VFB adalah 5,5\% - 7\%, nilai stabilitas dan MQ adalah semua variasi kadar aspal, dan nilai flow adalah 5\% dan 5,5\%. Dengan demikian kadar aspal optimum adalah 5,5\% karena memenuhi semua syarat spesifikasi beton aspal AC-WC. (Widianty, 2018b).

Pratomo (2016), penggunaan aspal modifikasi dengan penambahan plastik LLDPE pada lapisan aspal beton AC-BC dengan variasi kadar 1 - $9 \%$ dari berat aspal menghasilkan nilai stabilitas yang semakin meningkat seiring bertambahnya kadar LLDPE. Namun dari nilai VIM nya tidak ada yang memenuhi syarat spesifikasi. Selain itu nilai penetrasi yang dihasilkan semakin menurun dengan semakin bertambahnya kadar LLDPE.

Dari uraian diatas diharapkan rencana penelitian ini dapat menghasilkan prosentase kadar aspal modifikasi serbuk serat pelepah batang pisang yang tepat berdasarkan karakteristik campuran beton aspal lapis pengikat $\mathrm{AC}-\mathrm{BC}$ untuk menghasilkan campuran yang lebih tahan terhadap temperatur tinggi.

\section{BAHAN DAN METODE}

\section{Alat dan Bahan}

Alat yang digunakan dalam penelitian berupa: alat uji aspal (penetrometer, bituminous softening point, cleveland open cup, ductility testing machine, piknometer dan timbangan, oven, oven untuk uji kehilangan berat), alat uji agregat (satu set saringan standar, alat uji berat jenis, piknometer, timbangan, oven, bak perendam, alat impact untuk keausan), alat uji campuran beton aspal (alat Marshall, cetakan benda uji berdiameter $100 \mathrm{~mm}$ dan tinggi $75 \mathrm{~mm}$ lengkap dengan pelat alas dan leher sambung, alat untuk mengeluarkan benda uji (Specimen Extractor), penumbuk, landasan pemadat dan bak perendam

Bahan penelitian yang digunakan antara lain : pelepah batang pisang, $\mathrm{NaOH}$ (Soda Api), air aquades, aspal pen 60/70 dan agregat diperoleh dari PT. Kresna Karya Pringgabaya.

\section{Metode}

Metode yang digunakan dalam penelitian ini merupakan metode eksperimen. Eksperimen dilaksanakan di Laboratorium Transportasi dan Rekayasa Jalan Raya Jurusan Teknik Sipil Fakultas Teknik Universitas Mataram.

\section{Pelaksanaan dan Pemeriksaan Penelitian}

a) Persiapan dan Pemeriksaan bahan

Aspal yang digunakan untuk penelitian ini adalah aspal murni 60/70 yang ditambah dengan serbuk serat pelepah batang pisang sebanyak $0,1 \%$ dari total aspal. Besarnya prosentase 
penambahan serbuk serat pelepah batang pisang ini didasarkan dari hasil penelitian sebelumnya (Widianty, 2018) tentang pengaruh penambahan serbuk serat pelepah batang pisang terhadap karakteristik sifat fisik aspal. Pengujian berupa uji penetrasi, uji titik lembek, uji titik nyala dan titik bakar, uji daktilitas, uji berat jenis, uji kehilangan berat.

Sedangkan pengujian agregat berupa : berat jenis, penyerapan air, kelekatan agregat terhadap aspal dan keausan dengan alat impact (agregat kasar). Pengujian yang dilakukan untuk agregat halus adalah: berat jenis, penyerapan air, dan pengujian yang untuk filler adalah: berat jenis.

b) Persiapan benda uji

Pembuatan benda uji briket campuran beton aspal lapis pengikat AC-BC menggunakan agregat dengan gradasi menerus (dense graded). Selanjutnya dibuat benda uji dengan kadar aspal selang $0,5 \%$. Rancangan benda uji untuk menentukan kadar aspal optimum menggunakan variasi kadar aspal modifikasi 5\%; 5,5\%; 6\%; 6,5\% dan $7 \%$.

c) Pemeriksaan benda uji

Pemeriksaan benda uji berupa sifat volumetrik dan mekanis campuran beton aspal lapis pengikat AC-BC. Pemeriksaan sifat volumetrik dilakukan dengan melakukan pemeriksaan berat jenis bulk beton aspal dan berat jenis maksimum beton aspal menggunakan kadar aspal yang telah ditetapkan. Kemudian dihitung besaran volumetrik dari beton aspal, yaitu rongga antara mineral agregat (VMA) dan rongga dalam campuran (VIM) dan rongga terisi aspal (VFB). Pemeriksaan mekanis dilakukan dengan alat marshal berupa stabilitas dan flow.

Analisis Data

Data yang didapat dari pengujian sifat volumetrik dan mekanis dilanjutkan dengan pengolahan dan analisis data. Analisis data dilakukan menggunakan metode statistik yaitu analisis regresi. Variabel pada penelitian ini terdiri dari variabel bebas yaitu kadar aspal modifikasi dan variabel tidak bebas berupa nilai VMA, VIM, VFB, stabilitas, flow dan marshall quetions. Muhidin (2007), kekuatan hubungan antara 2 variabel disebut dengan koefisien korelasi (r). Nilai Koefisien $\mathrm{r}$ akan selalu berada di antara -1 sampai +1 . Kekuatan hubungan tersebut apakah hubungan sangat lemah, lemah, cukup, kuat, atapun sangat kuat. Selanjutnya untuk mendapatkan kadar aspal modifikasi optimum dilakukan dengan menggunakan grafik hubungan antara kadar aspal modifikasi serbuk serat pelepah batang pisang 0,1\% dengan sifat volumetrik dan mekanis beton aspal AC-BC.

\section{HASIL DAN PEMBAHASAN}

\section{Hasil Pemeriksaan Aspal Modifikasi}

Aspal modifikasi serbuk serat batang pisang merupakan campuran aspal 60/70 ditambah serbuk serat pelepah batang pisang sebanyak $0,1 \%$ dari prosentase aspal murni. Pemeriksaan bahan aspal modifikasi terdiri dari pemeriksaan penetrasi, daktilitas, titik nyala, titik lembek, berat jenis, dan kehilangan berat. Hasil pemeriksaan aspal modifikasi disajikan pada Tabel 1. 
Tabel 1. Hasil pemeriksaan aspal modifikasi serbuk serat batang pisang

\begin{tabular}{clcc}
\hline No. & \multicolumn{1}{c}{ Jenis Pemeriksaan } & Persyaratan*) & Hasil Pemeriksaan \\
\hline 1. & Penetrasi, $25^{\circ} \mathrm{C}, 100$ gram, 5 detik; $0,1 \mathrm{~mm}$ & $60-70$ & 62 \\
2. & Daktilitas; $25^{\circ} \mathrm{C},(\mathrm{cm})$ & $>100$ & 103,4 \\
3. & Titik nyala; ${ }^{\circ} \mathrm{C}$ & $\min 232$ & $>285$ \\
4. & Titik lembek; ${ }^{\circ} \mathrm{C}$ & $48-58$ & 51,5 \\
5. & Berat jenis & min 1,0 & 1,022 \\
6. & Kehilangan berat; \% berat & maks 0,8 & 0,32 \\
\hline
\end{tabular}

Sumber: *) SNI $8198: 2015$

\section{Hasil Pemeriksaan Agregat}

Agregat sebagai bahan yang mendominasi dalam suatu campuran beraspal tentu akan sangat mempengaruhi kualitas dari campuran. Hasil pemeriksaan disajikan pada Tabel 2.

Tabel 2. Hasil pemeriksaan agregat

\begin{tabular}{cccccc}
\hline & & & \multicolumn{3}{c}{ Hasil Pemeriksaaan } \\
\cline { 3 - 6 } No. & Jenis Pemeriksaan & Persyaratan*) & $\begin{array}{c}\text { Agregat } \\
\text { Kasar }\end{array}$ & $\begin{array}{c}\text { Agregat } \\
\text { Halus }\end{array}$ & Filler \\
\hline 1. & Berat jenis bulk & $\geq 2,50$ & 2,73 & 2,76 & 2,70 \\
2. & Berat jenis semu & $\geq 2,50$ & 2,84 & 2,81 & - \\
3. & Berat jenis efektif & $\geq 2,50$ & 2,79 & 2.79 & - \\
4. & Penyerapan terhadap air $(\%)$ & $\leq 3,00$ & 1,44 & 0,63 & - \\
5. & Keausan dengan alat impact $(\%)$ & $\leq 30,00$ & 7,69 & - & - \\
6. & Kelekatan agregat terhadap aspal $(\%)$ & $\geq 95,00$ & 100,00 & - & - \\
\hline
\end{tabular}

Sumber: *) SNI $8198: 2015$

Dari hasil pemeriksaan yaitu Tabel 1, aspal modifikasi serbuk serat batang pisang dan Tabel 2, agregat menunjukkan bahwa kedua bahan tersebut memenuhi syarat sebagai bahan campuran beton aspal.

\section{Penentuan Proporsi Agregat dan Aspal modifikasi}

Proporsi campuran agregat diperoleh dengan melakukan pendekatan proporsional sesuai dengan spesifikasi yang dituju. Dalam penelitian ini, spesifikasi yang dituju adalah batas tengah dari gradasi agregat untuk Laston AC-BC berdasarkan standar dari Bina Marga. Dari nilai tengah persen lolos selanjutnya dapat ditentukan persen tertahan untuk masing-masing ukuran saringan. Spesifikasi gradasi agregat untuk AC-BC dapat dilihat pada Tabel 3. Besarnya proporsi masing-masing fraksi agregat ditentukan dari persen tertahan pada fraksi itu sendiri. Sehingga didapatkan proporsi fraksi agregat kasar (CA), yaitu persen tertahan pada ukuran saringan 4,75 mm sebesar 45\%. Proporsi fraksi agregat halus (FA) yaitu antara persen tertahan ukuran saringan $0,075 \mathrm{~mm}$ dan persen lolos ukuran saringan 4,75 mm sebesar $49 \%$ dan proporsi filler yaitu persen lolos ukuran saringan $0,075 \mathrm{~mm}$ sebesar $6 \%$. 
Tabel 3. Gradasi agregat campuran AC-BC untuk menentukan proporsi campuran agregat

\begin{tabular}{cccccc}
\hline No. & $\begin{array}{c}\text { Ukuran saringan } \\
(\mathbf{m m})\end{array}$ & $\begin{array}{c}\text { Spesifikasi } \\
\text { Lolos }(\boldsymbol{\%})\end{array}$ & $\begin{array}{c}\text { Nilai Tengah } \\
(\boldsymbol{\%})\end{array}$ & $\begin{array}{c}\text { \% kumulatif } \\
\text { tertahan }\end{array}$ & $\begin{array}{c}\text { \% } \\
\text { saringan }\end{array}$ \\
\hline 1. & 25 & 100 & 100 & & \\
2. & 19 & $90-100$ & 95 & 5 & 5.0 \\
3. & 12,5 & $75-90$ & 83 & 18 & 12.5 \\
4. & 9,5 & $66-82$ & 74 & 26 & 8.5 \\
5. & 4,75 & $46-64$ & 55 & 45 & 19.0 \\
6. & 2,36 & $30-49$ & 40 & 61 & 15.5 \\
7. & 1,18 & $18-38$ & 28 & 72 & 11.5 \\
8. & 0,600 & $12-28$ & 20 & 80 & 8.0 \\
9. & 0,300 & $7-20$ & 14 & 87 & 6.5 \\
10. & 0,150 & $5-13$ & 9 & 91 & 4.5 \\
11. & 0,075 & $4-8$ & 6 & 94 & 3.0 \\
12. & Filler & & & 6 & 6 \\
\hline
\end{tabular}

Sumber: Hasil perhitungan (2019)

Variasi kadar aspal didapatkan dengan menentukan nilai kadar aspal rencana $(\mathrm{Pb})$. menggunakan persamaan yaitu : $\mathrm{Pb}=0,035(\% \mathrm{CA})+0,045(\% \mathrm{FA})+0,18(\% \mathrm{FF})+\mathrm{K}$ dengan nilai konstanta sebesar 1,0. Sehingga nilai kadar aspal rencana $(\mathrm{Pb})$ sebesar 5,86\% (dibulatkan $6,0 \%$ ) yang dipakai sebagai dasar untuk membuat rancangan campuran beton aspal AC-BC. Variasi kadar aspal yang dibuat menggunakan lima variasi yaitu $\mathrm{Pb}-1 ; \mathrm{Pb}-0,5 ; \mathrm{Pb} ; \mathrm{Pb}+0,5$ dan $\mathrm{Pb}+1$ sehingga menjadi 5\%; 5,5\%; 6\%; 6,5\%; dan 7\% dimana aspal yang digunakan adalah aspal modifikasi serbuk serat pelepah batang pisang.

\section{Pemeriksaan Volumetrik dan Mekanis Beton Aspal AC-BC}

Benda uji campuran beton aspal AC-BC dirancang dengan 5 variasi kadar aspal modifikasi serbuk serat batang pisang yaitu 5\%; 5,5\%; 6\%; 6,5\% dan 7\% dan dibuat 3 sampel untuk masing-masing variasi. Pemeriksaan volumetrik campuran aspal terdiri dari VIM, VMA, dan VFB serta pemeriksaan mekanis berupa stabilitas, flow dan marshall quetions (MQ). Hasil pemeriksaan disajikan pada Tabel 4.

Tabel 4. Hasil Pemeriksaan Volumetrik dan Mekanis Beton Aspal AC-BC

\begin{tabular}{llccccccc}
\hline \multirow{2}{*}{ No. Jenis } & \multirow{2}{*}{ Satuan } & \multirow{2}{*}{ Syarat } & \multicolumn{5}{c}{ Kadar aspal modifikasi (\%) } \\
\cline { 6 - 9 } & Pemeriksaan & & & $\mathbf{5}$ & $\mathbf{5 , 5}$ & $\mathbf{6}$ & $\mathbf{6 , 5}$ & $\mathbf{7}$ \\
\hline 1 & VMA & $\%$ & $\min 14$ & 15.26 & 15.58 & 15.62 & 15.72 & 16.44 \\
2 & VIM & $\%$ & $3-5$ & 4.41 & 3.50 & 2.28 & 1.10 & 0.65 \\
3 & VFB & $\%$ & $\min 65$ & 71.14 & 77.64 & 85.43 & 92.98 & 96.02 \\
1 & Stabilitas & $\mathrm{kg}$ & $\min 800$ & 3084.85 & 2721.85 & 2697.39 & 2359.32 & 1867.56 \\
2 & Flow & $\mathrm{mm}$ & $2-4$ & 2.18 & 2.40 & 2.98 & 3.02 & 3.67 \\
3 & MQ & $\mathrm{kg} / \mathrm{mm}$ & $\min 250$ & 1495.06 & 1366.78 & 906.97 & 791.28 & 514.63 \\
\hline
\end{tabular}

Sumber: Hasil perhitungan (2019)

Berdasarkan Tabel 4, maka dapat dibuat grafik hubungan antara variasi kadar aspal yang ditambah dengan serbuk serat batang pisang dengan VMA, VIM dan VFB, stabilitas, flow dan MQ. 


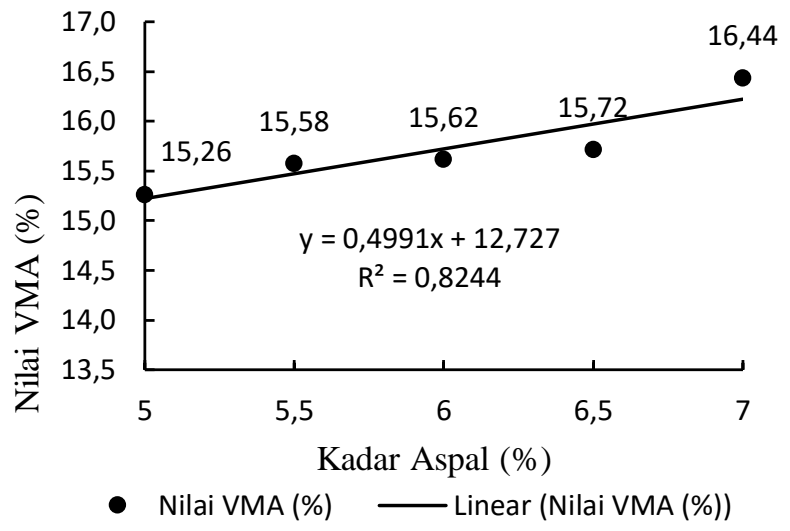

Gambar 1. Hubungan Kadar Aspal dan VMA

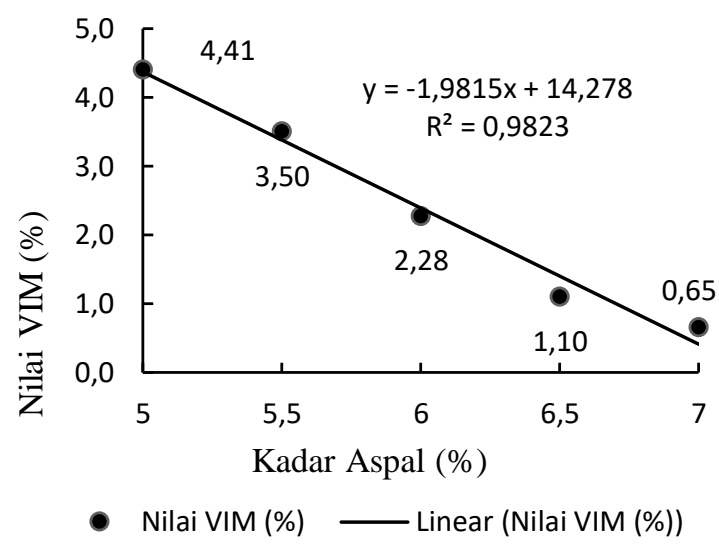

Gambar 2. Hubungan Kadar Aspal dan VIM

\section{Rongga antara agregat (VMA)}

Banyaknya rongga pori di antara butir-butir agregat didalam beton aspal padat dinyatakan dalam persen. Berdasarkan Gambar 1 diperoleh hubungan antara variasi kadar aspal nilai VMA yaitu semakin tinggi kadar aspal modifikasi serbuk serat pelepah batang pisang 0,1\% maka nilai rongga di antara mineral agregat (VMA) akan semakin naik. Hal ini berarti makin tinggi kadar aspal yang dipakai maka rongga yang dapat diisi oleh aspal juga semakin besar. Dari spesifikasi untuk campuran beton aspal AC-BC ternyata semua variasi kadar aspal dari $5 \%$ sampai 7\% dengan nilai VMA sebesar 15,577\% - 16,436\% memenuhi persyaratan, karena nilai minimum VMA adalah sebesar 14\%. Besarnya nilai korelasi (r) diperoleh sebesar 0,9079 (0,9-1) yang artinya kadar aspal sangat kuat berpengaruh terhadap nilai VMA. Karena seiring dengan bertambahnya kadar aspal nilai VMA mengalami peningkatan maka korelasi ini merupakan korelasi positif. Koefisien determinasi $\left(\mathrm{R}^{2}\right)$ yang diperoleh adalah sebesar 0,8244 yang berarti bahwa kadar aspal berpengaruh terhadap nilai VMA sebesar $82,44 \%$.

\section{Rongga dalam campuran (VIM)}

Rongga dalam campuran dibutuhkan untuk tempat bergesernya agregat-agregat karena adanya tambahan repetisi beban lalu lintas, atau sebagai tempat bila aspal melunak akibat meningkatnya temperatur udara. Hasil pemeriksaan nilai VIM terhadap variasi kadar aspal dapat disajikan pada Gambar 2. Kadar aspal modifikasi yang memenuhi persyaratan adalah kadar aspal 5\% dan 5,5\% dengan nilai VIM sebesar 3,5 dan 4,41 karena persyaratan VIM berada pada rentang 3,0 - 5,0. Nilai VIM lebih dari 5,0 dapat meningkatkan oksidasi aspal yang berdampak pada penuaan aspal sehingga durabilitas aspal menurun. Namun bila VIM kurang dari 3,0 mengakibatkan perkerasan mengalami bleeding saat suhu udara meningkat. Gambar 2 menunjukkan bahwa semakin tinggi kadar aspal modifikasi maka rongga dalam campuran semakin kecil, karena rongga akan terisi oleh aspal itu sendiri. Korelasi antara kadar aspal dengan VIM merupakan korelasi negatif karena nilai VIM mengalami penurunan. Besarnya koefisien determinasi $\left(\mathrm{R}^{2}\right)$ yang diperoleh adalah 0,9823 , artinya pengaruh kadar aspal terhadap nilai VIM sebesar 98,23\%. Sedangkan nilai korelasinya sebesar -0,9911 yang berarti pengaruh kadar aspal sangat kuat terhadap nilai VMA. 


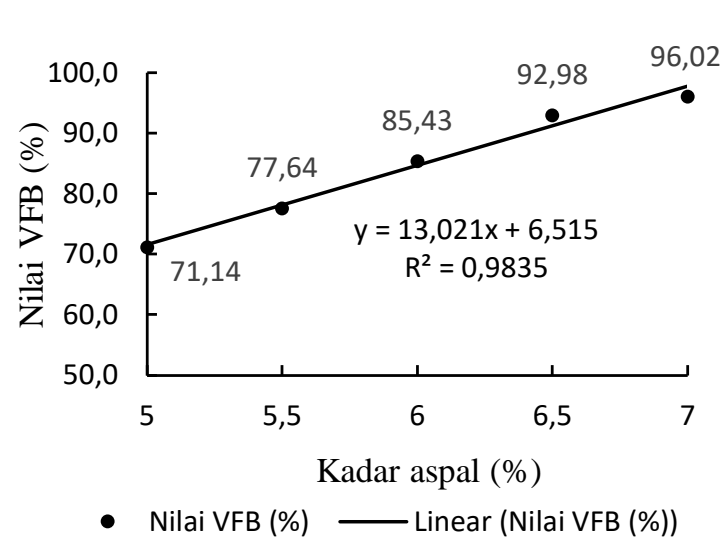

Gambar 3. Hubungan Kadar Aspal dan VFB

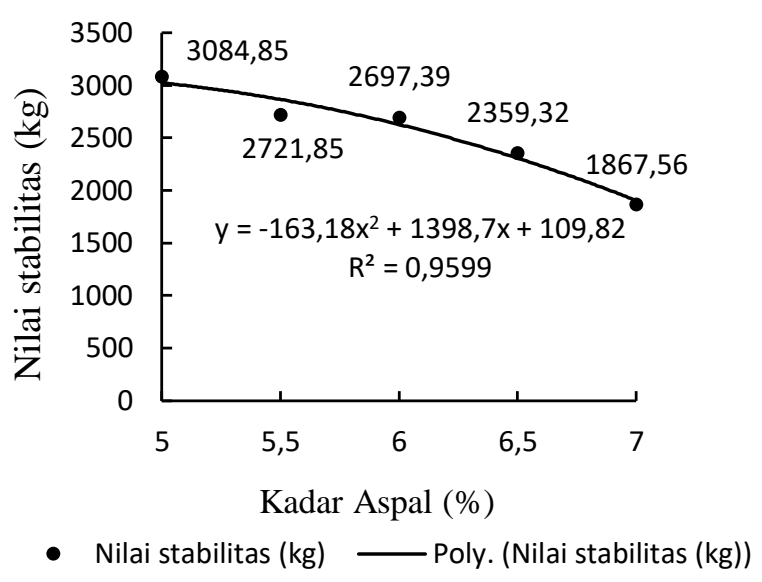

Gambar 4. Hubungan Kadar Aspal dan Stabilitas

\section{Rongga terisi Aspal (VFB)}

Berdasarkan Gambar 3 diperoleh nilai VFB semakin meningkat seiring meningkatnya kadar aspal. Hal ini menunjukkan bahwa semakin tinggi kadar aspal yang digunakan, maka semakin banyak aspal efektif yang masuk ke dalam rongga campuran dan menyelimuti campuran aspal. Variasi kadar aspal 5\% sampai 7\% memiliki nilai VFB diatas $65 \%$ yang berarti semua memenuhi syarat spesifikasi. Nilai koefisien determinasi $\left(R^{2}\right)$ sebesar 0,9835 menunjukkan bahwa kadar aspal berpengaruh terhadap nilai VFB sebesar 98,35\%. Jika dilihat dari nilai korelasi yaitu sebesar 0,9917 yang menunjukkan bahwa hubungan keduanya saling berpengaruh sangat kuat $(0,9-1)$.

\section{Stabilitas}

Tingkat keawetan suatu campuran aspal dapat dilihat dari nilai stabilitas campurannya, karena nilai stabilitas menunjukkan besarnya beban maksimum yang dapat diterima oleh suatu campuran beton aspal saat terjadi keruntuhan. Stabilitas yang rendah mengakibatkan perkerasan tidak dapat memikul beban yang tinggi, namun stabilitas yang terlalu tinggi dapat menghasilkan perkerasan yang terlalu kaku sehingga tingkat keawetan campuran malah berkurang. Tabel 4 dan Gambar 4 menunjukkan hubungan antara stabilitas dengan variasi kadar aspal modifikasi. Nilai stabilitas dari variasi kadar aspal 5\% - 7\% semuanya memenuhi persyaratan spesifikasi beton aspal AC-BC yaitu bernilai diatas $800 \mathrm{~kg}$. Nilai stabilitas tertinggi dicapai pada kadar aspal 5\% yaitu sebesar 3084,85 kg. Seiring dengan bertambahnya kadar aspal nilai stabilitasnya semakin turun, hal ini disebabkan karena rongga diantara agregat semakin kecil sehingga kadar aspal yang terlalu tinggi pada campuran menyebabkan campuran akan menjadi lembek (bleeding) sehingga stabilitasnya pun akan menurun. Besarnya koefisien determinasi $\left(\mathrm{R}^{2}\right)$ diperoleh sebesar 0,9599 yang menunjukkan bahwa pengaruh kadar aspal terhadap nilai stabilitas adalah sebesar 95,99\%. Sedangkan nilai korelasi (R) diperoleh sebesar -0,9797 yang berarti kadar aspal sangat kuat pengaruhnya terhadap nilai stabilitas. 


\section{Flow (pelelehan)}

Dari Tabel 4 dan Gambar 5 diperoleh bahwa nilai flow mengalami peningkatan seiring dengan bertambahnya kadar aspal. Nilai flow menunjukkan besarnya total deformasi dari campuran beton aspal sampai mencapai titik beban maksimum pada saat pengujian stabilitas. Kadar aspal semakin banyak membuat campuran aspal akan menjadi semakin elastis sehingga lebih mudah mengalami deformasi atau penurunan. Nilai flow yang dihasilkan pada variasi kadar aspal 5\% - 7\% yaitu sebesar 2,18\% - 3,67\% berada pada rentang 2 - 4 yang artinya besarnya deformasi yang timbul masih memenuhi syarat spesifikasi. Besarnya pengaruh antara kadar aspal modifikasi dengan flow adalah sebeesar 94,98\% yang ditunjukkan dari nilai koefisien determinasi $\left(\mathrm{R}^{2}\right)$ diperoleh sebesar 0,9498. Sedangkan dari nilai koefisien korelasi (R) diperoleh sebesar 0,9746 menunjukkan bahwa kadar aspal modifikasi sangat kuat berpengaruh terhadap nilai flow.

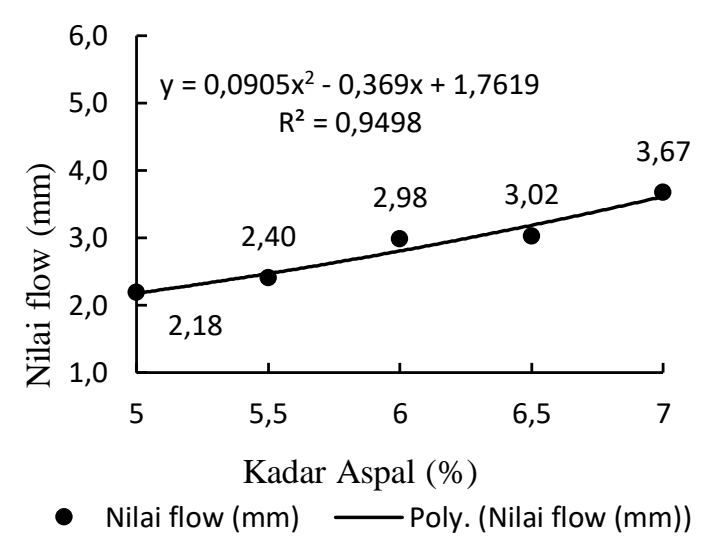

Gambar 5. Hubungan Kadar Aspal dan Flow

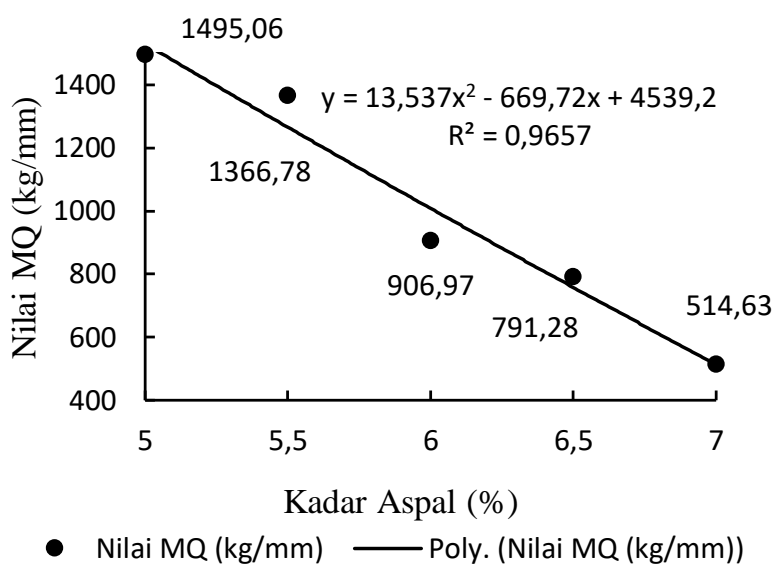

Gambar 6. Hubungan Kadar Aspal dan MQ

\section{Marshall Quotient (MQ)}

Perbandingan antara stabilitas dan flow merupakan nilai marshall quetient. Nilai MQ ini dapat mencerminkan tingkat kekakuan suatu campuran. Semakin tinggi nilai MQ maka makin tinggi kekakuan campuran. Namun MQ yang terlalu rendah dapat menyebabkan perkerasan tidak cukup kuat memikul beban. Oleh karena itu Bina Marga mensyaratkan nilai MQ minimal $250 \mathrm{~kg} / \mathrm{mm}$. Hubungan antara kadar aspal dan nilai MQ sangat kuat pengaruhnya, hal ini terlihat dari nilai koefisien korelasi $(\mathrm{R})$ bernilai $-0,9827$ (0,9-1, kategori sangat kuat) dan pengaruh kadar aspal terhadap nilai MQ sebesar 96,57\%. Gambar 6 menunjukkan bahwa semakin tinggi kadar aspal maka nilai MQ mengalami penurunan. Hal ini disebabkan karena nilai flow yang juga semakin tinggi. Walaupun nilai MQ mengalami penurunan namun campuran masih cukup kuat dalam memikul beban karena masih jauh diatas $250 \mathrm{~kg} / \mathrm{mm}$ yaitu sebagai syarat minimal nilai MQ. Dari 5 variasi kadar aspal terlihat bahwa semua variasi memenuhi persyaratan untuk Marshall Quotient.

\section{Kadar Aspal Modifikasi Optimum}

Penentuan kadar aspal optimum dari aspal modifikasi dengan tambahan 0,1\% serbuk serat pelepah batang pisang pada campuran beton aspal lapis pengikat AC-BC diperoleh dari hasil pemeriksaan volumetrik dan pemeriksaan mekanis. Tabel 5 merupakan hasil rekapitulasi 
nilai volumetrik dan mekanis campuran beton aspal AC-BC. Hasil tersebut digunakan sebagai dasar untuk menentukan besarnya kadar aspal modifikasi optimum, yaitu dengan cara memilih variasi kadar aspal yang memenuhi semua syarat spesifikasi beton aspal AC-BC. Dalam penelitian ini dihasilkan kadar aspal yang memenuhi persyaratan semua parameter volumetrik dan mekanis adalah kadar aspal modifikasi 5\% dan 5,5\%. Untuk mendapatkan nilai kadar aspal optimum dilakukan dengan mengambil nilai tengah dari kadar aspal yang memenuhi persyaratan. Sehingga 5,25\% kadar aspal modifikasi serbuk serat pelepah batang pisang merupakan besarnya kadar aspal optimum (KAO). Dengan demikian untuk membuat campuran beton aspal lapis pengikat (AC-BC) dengan bahan aspal modifikasi serbuk serat pelepah batang pisang yang menghasilkan kinerja campuran yang paling baik adalah memakai kadar aspal sebesar 5,25\%.

Tabel 5. Penentuan kadar aspal optimum (KAO)

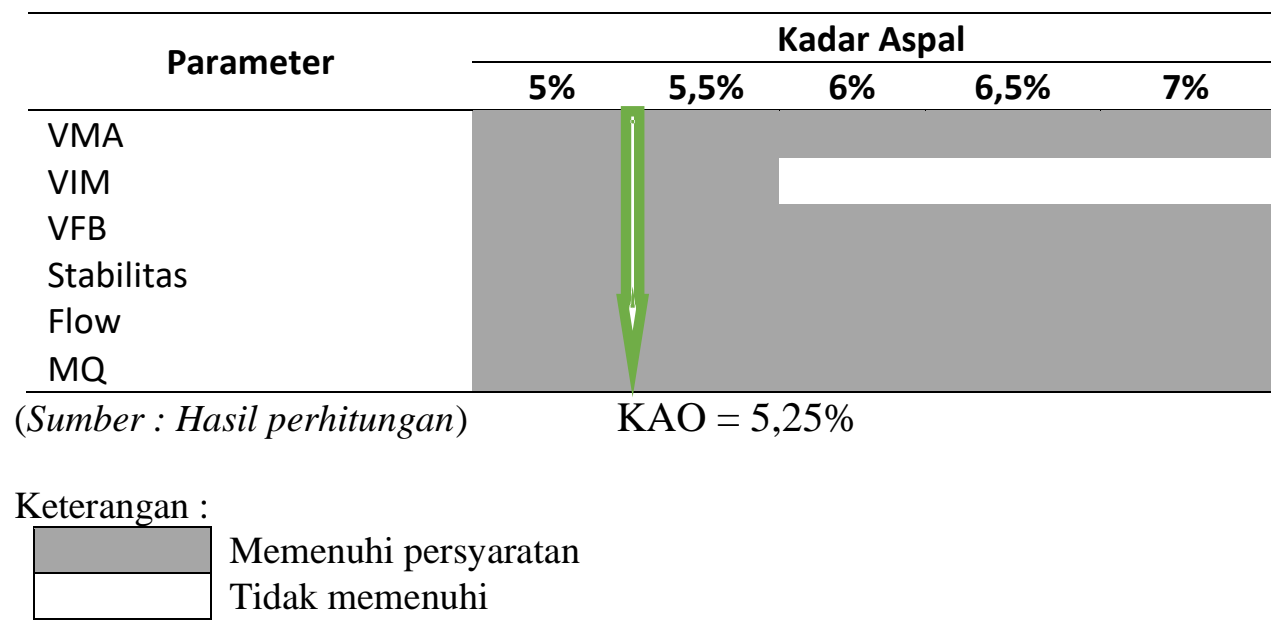

\section{KESIMPULAN}

Penggunaan aspal modifikasi dengan penambahan $0,1 \%$ serbuk serat batang pisang pada aspal 60/70 pada beton aspal lapis pengikat (AC-BC) menghasilkan nilai VMA dan VFB serta flow yang semakin meningkat seiring dengan meningkatnya kadar aspal modifikasi yang digunakan. Sedangkan nilai VIM, stabilitas dan MQ mengalami penurunan bila kadar aspal meningkat. Kadar aspal 5\% dan 5,5\% memenuhi semua syarat spesifikasi. Penggunaan kadar aspal lebih dari 5,5\% menyebabkan campuran aspal akan mengalami bledding karena kelebihan aspal akibat kurangnya rongga didalam campuran. Sehingga besarnya kadar aspal modifikasi optimum adalah sebesar 5,25\% yaitu nilai rata-rata kadar aspal yang memenuhi persyaratan beton aspal lapis pengikat AC-BC.

\section{Ucapan Terima Kasih}

Terima kasih penulis ucapkan pada Anisyah dan Auliya Isolihati yang membantu dalam mendapatkan data laboratorium. 


\section{DAFTAR PUSTAKA}

Badan Standarisasi Nasional. 2015, SNI 8198-2015: Spesifikasi Campuran Beraspal Panas Bergradasi Menerus (Laston). Jakarta: Standar Nasional Indonesia.

Mashuri, Patunrangi, J. 2011. Perubahan Karakteristik Mekanis Aspal Yang Ditambahkan Sulfur Sebagai Bahan Tambah. Jurnal Mektek. 13(2) halaman 111-120.

Muhidin, SA, Abdurrahman, M. 2007. Analisis Korelasi, Regresi, dan Jalur dalam Penelitian. Bandung: CV Pustaka Setia.

Pratomo, P. 2016. Aspal Modifikasi dengan penambahan plastik Low Liniear Density Poly Ethylene (LLDPE) ditinjau dari karakteristik Marshall dan uji Penetrasi pada lapisan Aspal Beton (AC-BC). Jurnal Rekayasa. 20(3) halaman 155-165.

Sukirman, S. 2016. Beton Aspal Campuran Panas. Jakarta: Penerbit Yayasan Obor Indonesia.

Widianty, D. 2018a, Pengaruh Penambahan Serbuk Serat Pelepah Batang Pisang Terhadap Karakteristik Sifat Fisik Aspal, Jurnal Rekayasa Sipil dan Lingkungan. 2(1) halaman 67-76.

Widianty, D. 2018b. Kinerja Campuran Beton Aspal Wearing Coarse dengan Tambahan Serbuk Serat Pelepah Batang Pisang. Jurnal Spektrum Sipil. 5(1) halaman 11-22. 